\title{
PENINGKATAN HASIL BELAJAR SISWA SD MELALUI PENDEKATAN CONCRETE-PICTORIAL-ABSTRACT (CPA)
}

\author{
Aan Yuliyanto ${ }^{1}$, Hafiziani Eka Putri ${ }^{2}$, dan Puji Rahayu ${ }^{2}$ \\ Guru SD Labschool UPI Kampus Purwakarta ${ }^{1}$ \\ Dosen Universitas Pendidikan Indonesia Kampus Purwakarta ${ }^{2}$
}

\section{Kata Kunci : \\ Pendekatan Concrete- \\ Pictorial-Abstract (CPA), \\ Hasil Belajar (HB), \\ Kemampuan Awal Matematis \\ (KAM) dan Siswa Sekoah \\ Dasar

\begin{abstract}
This research was conducted because of the low level of Learning Outcome of students uses Concrete Pictorial Abstract approach (CPA) if considered by whole and based on Prior Mathematical Ability (PMA). The research method is quasi experimental research with nonequivalent pretest posttest control group design on the main discourse volume of cube and cuboid toward 119 Elementary School students in Purwasukasi. Based on the result of the research, it can be concluded that: Improvement $L O$ of students who get the learning with a CPA approach are better than students who get the conventional learning in terms of overall or PMA group.
\end{abstract}

Email penulis:

aanyuliyanto@student.upi.edu

\begin{abstract}
ABSTRAK
Penelitian ini dilakukan karena masih rendahnya hasil belajar siswa. Penelitian ini bertujuan untuk melihat peningkatan Hasil Belajar (HB) siswa menggunakan pendekatan Concrete Pictorial Abstract (CPA) ditinjau secara keseluruhan maupun berdasarkan Kemampuan Awal Matematis (KAM). Metode penelitian yang dilakukan yaitu penelitian kuasi eksperimen dengan desain nonequivalent pretest postest control group pada mata pelajaran matematika pokok bahasan volume bangun ruang Kubus dan Balok terhadap 119 siswa Sekolah Dasar di Purwasukasih. Instrumen penelitian yang digunakan adalah tes dan non tes. Berdasarkan hasil penelitian diperoleh dapat disimpulkan bahwa: Peningkatan HB siswa yang mendapatkan pembelajaran dengan pendekatan CPA lebih baik daripada siswa yang mendapatkan pembelajaran konvensional ditinjau dari keseluruhan maupun KAM.
\end{abstract}

\section{PENDAHULUAN}

Tujuan Pendidikan Nasional untuk mengembangkan potensi peserta didik agar menjadi manusia yang beriman dan bertaqwa kepada Tuhan Yang Maha Esa, berakhlak mulia, sehat, berilmu, cakap, kreatif, mandiri, dan menjadi warga negara yang demokratis, serta bertanggung jawab (Depdiknas, 2003). Tujuan kurikulum pembelajaran matematika yang tercantum dalam Permendiknas Nomor 22 tahun 2006 (dalam Badan Pengembangan Sumber Daya Manusia Pendidikan dan Penjaminan Mutu Pendidikan, 2011) salah satunya adalah "Memahami konsep matematika, menjelaskan keterkaitan antarkonsep dan mengaplikasikan 
konsep atau algoritma, secara luwes, akurat, efisien, dan tepat, dalam pemecahan masalah". Hal di atas dapat didefiniskan sebagai hasil belajar, Hasil belajar merupakan kemampuan yang dimiliki oleh peserta didik dari proses belajar yang dapat dilihat dari sikap, berbagai pengetahuan, dan berbagai keterampilan yang dimilikinya (Syam dan Ramlah, 2015). Namun hasil belajar setiap siswa tidaklah sama bahkan cenderung rendah hal ini sesuai dengan pernyataan Siregar (2013) "hasil belajar yang diperoleh siswa tidak semuanya sama, hal ini ditunjukan oleh adanya siswa yang memperoleh hasil yang baik dan ada pula siswa yang memperoleh hasil yang kurang baik". Hasil belajar matematika siswa yang rendah disebabkan banyak hal, seperti: padatnya kurikulum, media belajar yang tidak efektif, strategi pembelajaran yang dipilih oleh guru kurang tepat, evaluasi yang buruk, kemampuan guru kurang dapat membangkitkan motivasi belajar siswa, atau juga karena pendekatan pembelajaran yang masih bersifat konvensional sehingga siswa tidak terlibat dalam proses pembelajaran, Zulkardi (dalam Supardi, 2012). Berdasarkan masalah tersebut peneliti memberikan solusi dengan menggunakan pendekatan CPA, menurut Bernard (dalam Putri, Rahayu, dan Saptini 2016, hlm. 45) menjelaskan kelebihan pendekatan Concrete-PictorialAbstract (CPA), di antaranya: 1) Memberikan siswa cara yang terstruktur untuk belajar konsep-konsep matematika; 2) Siswa mampu membangun hubungan yang lebih baik ketika bergerak melalui tingkat pemahaman dari konkrit menuju abstrak; 3) Membuat belajar melibatkan semua siswa (termasuk orang-orang dengan ketidakmampuan belajar matematika); 4) Diajarkan eksplisit menggunakan pendekatan multi-sensori; 5) Mengikuti Universal Desain untuk pedoman Belajar.; 6) Penelitian telah membuktikan bahwa metode ini efektif; 7) Dapat digunakan di seluruh tingkatan kelas, dari Sekolah Dasar sampai SMA awal; 8) Selaras dengan standar NCTM; 9) Membantu siswa belajar konsep sebelum aturan belajar; 10) Dapat digunakan dalam kelompok kecil atau seluruh kelas. Adapun kekurangannya adalah ketika siswa lebih menggangap penggunaan benda-benda manipulatif dalam pembelajaran sebagai kegiatan yang hanya bermain saja untuk mengisi waktu daripada menyediakan peluang untuk meningkatkan pemahaman siswa terhadap matematika, maka penerapan pendekatan CPA dalam pembelajaran memberikan potensi jebakan bagi siswa dalam mengembangkan kemampuan matematisnya.

Pendekatan CPA atau CRA menurut Hoong, dkk. (dalam Pebrianti, Mulyani, dan Yuliartiningsih, 2016) mengungkapkan pendekatan CRA merupakan "pendekatan yang diadaptasi dari model Bruner yang memiliki tiga instruksi yang digunakan dalam pembelajaran dan sangat efektif untuk membantu siswa yang memiliki kesulitan dalam belajar matematika". Pendekatan CPA sesuai yang diungkapkan di atas berarti pendekatan dengan melalui tiga tahap yaitu Concrete sebagai tahap proses manipulasi, Pictorial sebagai tahap peghubung proses manipulasi dan Abstract sebagai penjelas bahwa matematika adalah pembelajaran yang menggunakan simbol, lambang, dan angka. Langkah pertama pendekatan CPA disebut tahap konkret, yaitu tahap "melakukan" dengan melibatkan benda nyata yang dimanipulasi untuk memecahkan masalah matematika. Pictorial (semi-konkret) dikenal sebagai tahap "melihat" dengan melibatkan penggunaan gambar untuk mewakili objek dalam memecahkan masalah matematika. Langkah terakhir disebut tahap abstrak dikenal sebagai tahap "simbolis" yang hanya melibatkan penggunaan angka dan simbol 
dalam memecahkan masalah matematika, Putri (2017, hlm. 44). Pembelajaran konvensional adalah proses belajar yang dalam menyampaikan materi menggunakan metode ceramah. Penggunaan metode ceramah cenderung pada bentuk komunikasi satu arah, Dalam hal ini kedudukan siswa sebagai penerima. Guru dituntut untuk menyampaikan materi dengan kalimat yang mudah dipahami peserta didik, Sugihartono (dalam Ainia, Kurniasih dan Sapti, 2012). Rumusan masalah penelitian ini adalah apakah terdapat peningkatan hasil belajar Matematika siswa Sekolah Dasar yang mendapat pembelajaran dengan Pendekatan CPA lebih baik daripada siswa yang mendapat pembelajaran konvensional ditinjau dari: Keseluruhan siswa, dan kemampuan awal matematis (KAM) siswa (tinggi, sedang, rendah).

\section{METODE PENELITIAN}

Penelitian ini adalah quasi experiment research. Desain penelitian ini Nonequivalent Control Group Design. Pada desain ini kelompok eksperimen dan kontrol tidak dipilih secara random, Sugiyono (2016). Populasi penelitian adalah siswa SDN di wilayah Purwasukasi. Sampel penelitian ini adalah siswa kelas V. Sampel kelas yang diteliti yaitu 4 kelas yang melibatkan dua SDN di kecamatan Cikampek, Kabupaten Karawang. Teknik pengambilan sampel ini dilakukan dengan teknik purposive sampling yaitu teknik pengambilan sampel dengan pertimbangan tertentu (Martono, 2014). Keseluruhan berjumlah 119 siswa yaitu 59 siswa kelompok eksperimen dan 60 siswa kontrol. Instrumen penelitian yang digunakan pada penelitian ini tercantum pada Tabel 1 sebagai berikut.

Tabel 1. Kisi-kisi Penyusunan Instrumen Penelitian

\begin{tabular}{lll}
\hline Variabel yang Diukur & Instrumen dan Teknik yang Diukur & Sumber Data \\
\hline KAM & Tes uraian & Siswa \\
Hasil Belajar $(\mathrm{HB})$ & Tes & Siswa \\
\hline
\end{tabular}

Berdasarkan uji instrumen hasil belajar didapat hasil sebanyak 5 butir soal valid, dengan kategori sedang. Keseluruhan instrumen hasil belajar memiliki kategori validitas sangat tinggi $\left(r_{x y}=0,80\right)$ dan reliabilitas tinggi $\left(r_{11}=0,89\right)$.

\section{HASIL DAN PEMBAHASAN}

\section{a. Analisis Deskriptif Data Tes HB}

Tes HB diberikan diawal (pretest) dan di akhir (postest) pembelajaran. Peningkatan HB siswa dilihat dari Gain ternormalisasi ( $N$-Gain). Kriteria peningkatan dikelompokkan berdasarkan kriteria yang dikemukakan oleh Meltzer (dalam Putri, 2015) sebagai berikut.

Tabel 2. Kriteria Peningkatan Hasil Belajar (HB) Siswa

\begin{tabular}{cc}
\hline Interval Peningkatan & Kriteria Peningkatan \\
\hline $\mathrm{N}-$ Gain $>0,7$ & Tinggi \\
$0,3<\mathrm{N}$-Gain $\leq 0,7$ & Sedang \\
$\mathrm{N}-$ Gain $\leq 0,3$ & Rendah \\
\hline
\end{tabular}

\section{1) Analisis Deskriptif Peningkatan HB siswa berdasarkan Pembelajaran dan Kelompok KAM}

Rekapitulasi hasil pretes dan postes HB serta $\mathrm{N}$-Gain berdasarkan pembelajaran dapat dilihat pada Tabel 3. 
Tabel 3. Rekapitulasi Data Hasil Belajar (HB) Siswa berdasarkan Pembelajaran

\begin{tabular}{|c|c|c|c|c|c|c|}
\hline \multirow{2}{*}{ Tes } & \multirow{2}{*}{ Pembelajaran } & \multicolumn{2}{|c|}{ Skor } & \multirow{2}{*}{$\bar{x}$} & \multirow{2}{*}{$s d$} & \multirow{2}{*}{ N-Gain } \\
\hline & & Terkecil & Terbesar & & & \\
\hline PR-HB & \multirow{2}{*}{ CPA } & 2 & 17 & 7,58 & 3,14 & \multirow{2}{*}{0,43} \\
\hline PO-HB & & 3 & 19 & 12,86 & 3,97 & \\
\hline PR-HB & \multirow{2}{*}{ Konvensional } & 1 & 16 & 8,48 & 3,39 & \multirow{2}{*}{0,19} \\
\hline PO-HB & & 4 & 18 & 10,63 & 3,80 & \\
\hline
\end{tabular}

Keterangan: PR= Pretes; $\mathrm{PO}=$ Postes; $N$-Gain= Gain ternormalisasi.

Berdasarkan Tabel 3 nampak bahwa peningkatan HB siswa yang mendapatkan pembelajaran dengan pendekatan CPA lebih tinggi dari siswa yang mendapatkan pembelajaran konvensional. Meskipun kualifikasi peningkatan pada kelompok pembelajaran CPA berada pada kriteria sedang, dan kelompok pembelajaran konvensional berada kriteria rendah. Selanjutnya rekapitulasi hasil analisis $N$-Gain HB berdasarkan pembelajaran ditinjau dari kelompok KAM dapat dilihat pada Tabel 4.

Tabel 4. Rekapitulasi Hasil Peningkatan Hasil Belajar (HB) ditinjau dari KAM

\begin{tabular}{|c|c|c|c|c|c|}
\hline \multirow{2}{*}{ КАM } & \multirow{2}{*}{ Pembelajaran } & \multicolumn{2}{|c|}{ Skor N-Gain } & \multirow{2}{*}{$\bar{x} N$-Gain } & \multirow{2}{*}{$s d$} \\
\hline & & Terkecil & Terbesar & & \\
\hline \multirow{2}{*}{ Tinggi } & CPA & 0,00 & 1,00 & 0,60 & 0,41 \\
\hline & Konvensional & 0,00 & 0,80 & 0,53 & 0,24 \\
\hline \multirow{2}{*}{ Sedang } & CPA & 0,00 & 0,86 & 0,44 & 0,26 \\
\hline & Konvensional & 0,00 & 0,75 & 0,17 & 0,19 \\
\hline \multirow{2}{*}{ Rendah } & CPA & 0,00 & 0,60 & 0,39 & 0,21 \\
\hline & Konvensional & 0,00 & 0,46 & 0,12 & 0,18 \\
\hline
\end{tabular}

Berdasarkan Tabel 4 nampak bahwa peningkatan HB siswa untuk setiap kelompok KAM siswa yang mendapatkan pembelajaran dengan pendekatan CPA lebih tinggi dari siswa yang mendapat pembelajaran konvensional. Hampir pada setiap kelompok KAM di kedua kelompok pembelajaran, peningkatan $\mathrm{HB}$ siswa berada pada kriteria sedang, kecuali peningkatan HB siswa pada kelompok KAM sedang dan rendah yang mendapat pembelajaran dengan pendekatan konvensional berada pada kriteria rendah. Tabel 4 juga menunjukan bahwa peningkatan HB siswa kelompok KAM CPA tinggi lebih tinggi dari kelompok KAM sedang dan KAM rendah. Begitupun peningkatan HB siswa yang mendapatkan pembelajaran konvensional pada kelompok KAM tinggi lebih tinggi dari kelompok KAM sedang dan kelompok KAM rendah.

Dengan demikian, pembelajaran dengan pendekatan CPA dapat lebih meningkatkan HB siswa pada setiap kelompok KAM dibandingkan dengan pembelajaran konvensional. HB siswa pada kelompok KAM tinggi yang mendapat pembelajaran CPA lebih meningkat dan berkembang dari kelompok KAM sedang dan rendah. Selanjutnya. Berikut ini disajikan gambar untuk lebih memperjelas perbedaan peningkatan HB siswa berdasarkan kelompok pembelajaran ditinjau dari kelompok KAM. 


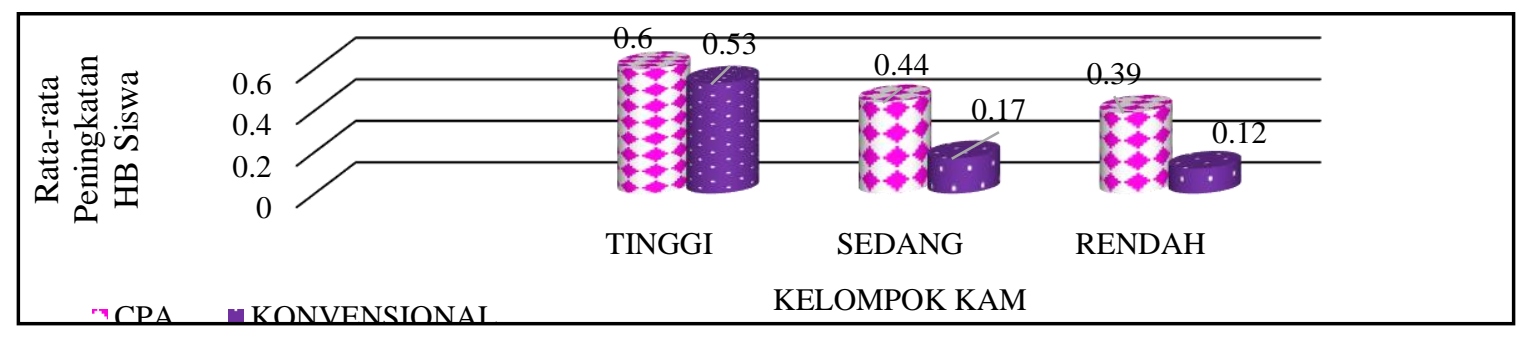

Gambar 1. Rata-rata Peningkatan Hasil Belajar (HB) ditinjau dari KAM

\section{b. Analisis Inferensial Data Hasil Belajar (HB)}

Secara deskriptif telah diungkapkan bahwa peningkatan HB siswa yang mendapatkan pembelajaran dengan pendekatan CPA lebih tinggi dari siswa yang mendapatkan pembelajaran konvensional, ditinjau secara keseluruhan maupun ditinjau berdasarkan kelompok KAM. Untuk menguji apakah perbedaan peningkatan tersebut signifikan atau tidak, maka dilakukan uji perbedaan rata-rata.

\section{1) Uji Perbedaan Rata-rata Peningkatan Hasil Belajar (HB) Siswa pada Kedua Kelompok Pembelajaran ditinjau secara Keseluruhan dan Kelompok KAM}

Rekapitulasi hasil uji perbedaan rata-rata peningkatan HB siswa berdasarkan pembelajaran ditinjau secara keseluruhan dapat dilihat pada Tabel 5 sebagai berikut.

Tabel 5. Rekapitulasi Uji Perbedaan Rata-rata Peningkatan Hasil Belajar (HB) ditinjau Keseluruhan

\begin{tabular}{ccccc}
\hline Pembelajaran & Uji Mann-Whitney & $\boldsymbol{Z}$ & $\boldsymbol{p}$-value (sig.1-arah) & Keterangan \\
\hline $\begin{array}{c}\text { CPA } \\
\text { Konvensional }\end{array}$ & 913,000 & $-4,594$ & 0,000 & $\mathrm{H}_{0}$ ditolak \\
\hline
\end{tabular}

Hipotesis untuk uji perbedaan rata-rata peningkatan HB ditinjau keseluruhan:

$\mathrm{H}_{0}: \mu_{1}=\mu_{2}$ Tidak ada perbedaan peningkatan rata-rata skor Hasil Belajar (HB) siswa yang mendapat pendekatan CPA dan siswa yang mendapat pembelajaran konvensional ditinjau keseluruhan.

$\mathrm{H}_{1}: \mu_{1}>\mu_{2}$ Peningkatan rata-rata skor HB siswa yang mendapat pendekatan CPA lebih baik dari siswa yang mendapat pembelajaran konvensional ditinjau keseluruhan.

Kriteria pengujian: Jika p-value (sig.1-arah) lebih besar dari 0,05 maka $\mathrm{H}_{0}$ diterima, dan dalam hal lainnya $\mathrm{H}_{0}$ ditolak. Berdasarkan hasil perhitungan pada Tabel 5, dapat dilihat bahwa untuk rata-rata peningkatan HB p-value (sig.2-arah) adalah 0,000 lebih kecil dari 0,05 maka $\mathrm{H}_{0}$ ditolak. Artinya jika ditinjau secara keseluruhan, peningkatan $\mathrm{HB}$ siswa yang mendapatkan pembelajaran dengan pendekatan CPA lebih baik secara signifikan daripada siswa yang mendapatkan pembelajaran konvensional. Setelah ditinjau secara keseluruhan berikutnya dilakukan pengujian yang ditinjau berdasarkan KAM siswa 


\section{Hipotesis untuk uji perbedaan rata-rata peningkatan HB kelompok KAM:}

$\mathrm{H}_{0}: \mu_{1}=\mu_{2}$ Tidak ada perbedaan peningkatan rata-rata skor Hasil Belajar (HB) siswa yang mendapat pendekatan CPA dan siswa yang mendapat pembelajaran konvensional ditinjau dari kelompok KAM.

$\mathrm{H}_{1}: \mu_{1}>\mu_{2}$ Peningkatan rata-rata skor HB siswa yang mendapat pendekatan CPA lebih baik dari siswa yang mendapat pembelajaran konvensional ditinjau dari kelompok KAM.

Kriteria pengujian: Jika p-value (sig.1-arah) lebih besar dari 0,05 maka $\mathrm{H}_{0}$ diterima, dan dalam hal lainnya $\mathrm{H}_{0}$ ditolak. Berdasarkan data pada Tabel 6 , nampak peningkatan KAM sedang dan rendah pada kedua pembelajaran bahwa p-value (sig.1-arah) lebih kecil dari 0,05, maka $\mathrm{H}_{0}$ ditolak. Oleh karena itu, dapat disimpulkan bahwa untuk kelompok KAM sedang dan rendah, peningkatan $\mathrm{HB}$ siswa yang mendapat pembelajaran dengan pendekatan CPA lebih baik secara signifikan daripada siswa yang mendapat pembelajaran konvensional. Untuk peningkatan KAM tinggi kedua pembelajaran bahwa p-value (sig.1-arah) lebih besar dari 0,05, maka $\mathrm{H}_{0}$ diterima. Oleh karena itu, dapat disimpulkan bahwa untuk kelompok KAM tinggi, peningkatan HB siswa yang mendapat pembelajaran dengan pendekatan CPA tidak berbeda secara signifikan daripada siswa yang mendapat pembelajaran konvensional

Tabel 6. Rekapitulasi Uji Perbedaan Rata-rata Peningkatan Hasil Belajar (HB) ditinjau KAM

\begin{tabular}{|c|c|c|c|c|c|c|}
\hline UJI HB & KAM & Pembelajaran & Mann-Whitney $U$ & $Z$ & $\begin{array}{c}\text { p-value (sig.1- } \\
\text { arah) }\end{array}$ & Ket \\
\hline \multirow{3}{*}{ Peningkatan } & Tinggi & $\begin{array}{c}\text { CPA } \\
\text { Konvensional }\end{array}$ & 66,500 & $-0,717$ & 0,242 & $\begin{array}{c}\mathrm{H}_{0} \\
\text { dierima }\end{array}$ \\
\hline & Sedang & $\begin{array}{c}\text { CPA } \\
\text { Konvensional }\end{array}$ & 270,500 & $-4,381$ & 0,000 & $\mathrm{H}_{0}$ ditolak \\
\hline & Rendah & $\begin{array}{c}\text { CPA } \\
\text { Konvensional }\end{array}$ & 16,000 & $-2,632$ & 0,004 & $\mathrm{H}_{0}$ ditolak \\
\hline
\end{tabular}

Dapat disimpulkan bahwa peningkatan HB siswa yang mendapat pembelajaran dengan pendekatan CPA lebih baik secara signifikan dari siswa yang mendapat pembelajaran konvensional, jika dilihat secara keseluruhan dan kelompok KAM, kecuali peningkatan tinggi.

Berdasarkan analisis hasil penelitian secara deskriptif diketahui bahwa, peningkatan HB siswa yang mendapatkan pendekatan CPA lebih baik daripada yang mendapatkan pembelajaran konvensional, begitupun dengan analisis hasil penelitian yang dilakukan secara inferensial juga menunjukkan hal yang serupa. Dengan demikian, dapat disimpulkan bahwa peningkatan HB siswa yang mendapat pembelajaran dengan pendekatan CPA lebih baik secara signifikan dari siswa yang mendapat pembelajaran konvensional, jika dilihat secara keseluruhan dan KAM, kecuali peningkatan tinggi. Hasil perhitungan peningkatan HB siswa berdasarkan kelompok KAM memperlihatkan keadaan yang hampir sama yaitu peningkatan HB siswa yang mendapat pendekatan CPA tidak berbeda secara signifikan dari siswa yang mendapat pembelajaran konvensional, jika dilihat secara keseluruhan dan 
kelompok KAM. Hal itu memberikan arti bahwa penerapan pembelajaran dengan pendekatan CPA memberikan pengaruh lebih besar terhadap peningkatan HB siswa daripada pembelajaran konvensional, baik ditinjau secara keseluruahan maupun kelompok KAM. Hasil ini sesuai dengan penelitian Witzel (dalam Putri, 2015) menyimpulkan bahwa, "siswa yang mendapatkan pembelajaran dengan pendekatan CPA mendapatkan nilai lebih baik daripada siswa yang mendapatkan pembelajaran konvensional”.

Peningkatan HB siswa yang mendapatkan pembelajaran dengan pendekatan CPA lebih baik secara signifikan daripada siswa yang mendapatkan pembelajaran konvensional dimungkinkan terjadi, karena tahapan pendekatan CPA memberikan peluang pada siswa untuk memahami konsep yang diajarkan dengan lebih mudah. Tahap pembelajaran yang dimulai dengan memanipulasi benda konkrit kemudian dilanjutkan dengan Pictorial seperti mengambar gambar geometris bangun, dan selanjutnya ke tahap abstrak dimana konsep matematika dimodelkan secara simbolis membantu siswa menyimpan memori mengenai suatu konsep, kemudian membentuk gambaran proses pemahaman konsep tersebut kedalam cara berpikirnya. Dengan diterapkannya pembelajaran pendekatan CPA yang tepat, maka kondisi pembelajaran yang melalui tahapan pendekatan CPA seperti inilah yang membuat siswa berhasil mengembangkan dan meningkatkan HB lebih dari siswa yang mendapatkan pembelajaran konvensional.

Meskipun demikian, peningkatan HB siswa yang mendapatkan pendekatan CPA masih belum maksimal. Dimana peningkatan HB siswa jika ditinjau secara keseluruhan. Untuk peningkatan HB siswa setiap kelompok KAM siswa yang mendapatkan pendekatan CPA lebih tinggi dari siswa yang mendapat pembelajaran konvensional. Hampir pada setiap kelompok KAM kedua kelompok pembelajaran, peningkatan HB siswa berada pada kriteria sedang, kecuali peningkatan HB siswa pada kelompok KAM sedang dan rendah yang mendapat pembelajaran pendekatan konvensional berada pada kriteria rendah. Salah satu faktor penyebab belum maksimalnya peningkatan HB siswa tersebut kemungkinannya disebabkan oleh kebiasaan siswa melewati pembelajaran dengan menerima penjelasan dari guru serta belum terbiasanya siswa belajar dengan menggunakan pendekatan CPA. Hasil peningkatan siswa kelompok KAM tinggi tetap berada diurutan paling atas. Sementara kelompok KAM sedang menempati posisi kedua dan untuk KAM rendah paling bawah.

Dari hasil analisis jurnal bahwa siswa merasa lebih terbantu dan mudah untuk memahami konsep matematika dengan adanya kesempatan belajar dengan benda-benda konkrit dan menyentuh secara langsung, membuatnya dalam bentuk gambar, dia memanipulasi secara langsung benda konkrit tersebut kemudian mencoba membuat gambar dari manipulasi benda tersebut untuk memantapkan pemahaman konsep matematika yang dimilikinya. Walaupun peningkatan HB siswa masih belum begitu maksimal, akan tetapi hasil penelitian ini menunjukkan bahwa pembelajaran dengan menggunakan pendekatan CPA memberikan manfaat dan pengaruh lebih baik daripada pembelajaran konvensional. Sebagaimana diungkapkan oleh Arvianto dan Masduki (2011) yaitu salah satu keuntungan melakukan pembelajaran dengan pendekatan CPA siswa dapat memahami makna pembelajaran, maka 
dari itu penerapan yang disertai langkah yang tepat mulai dari tahap konkrit, Pictorial dan abstrak akan memberikan pengaruh positif untuk siswa

\section{KESIMPULAN}

Penerapan pembelajaran dengan pendekatan CPA dapat dijadikan sebagai salah satu alternatif yang dapat digunakan untuk meningkatkan HB siswa. Dan untuk mendapatkan peningkatan HB siswa yang maksimal melaui penerapan pembelajaran dengan pendekatan CPA dalam pelaksanaan pembelajaran di dalam kelas diperlukan adanya waktu yang cukup yang dirancang seefektif mungkin untuk membahas materi yang diberikan pada setiap tahapan pembelajaran dengan pendekatan CPA serta pengelolaan proses pembelajaran di kelas, sehingga siswa dapat belajar secara tuntas untuk materi pada setiap tahapan (konkrit, Pictorial, Abstract). Penggunaan benda manipulatif (konkrit) yang variatif dan menantang pola pikir siswa juga diperlukan. Body language atau pembawaan suasana belajar yang kondusif dan menyenangkan terhadap dunia siswa SD yang sesuai harus diperhatikan, sehingga siswa tidak terjebak pada situasi belajar monoton dan membosankan.

\section{REFERENSI}

Ainia, Q., Kurniasih, N., \& Sapti, M. (2012). Eksperimentasi Model Pembelajaran Auditory Intellectually Repetition (AIR) terhadap Prestasi Belajar Matematika ditinjau dari Karakter Belajar Siswa Kelas VII SMP Negeri Se-Kecamatan Kaligesing Tahun 2011/2012. Seminar Nasional Matematika dan Pendidikan Matematika (pp. 710716). Yogyakarta: Pendidikan Matematika FPMIPA UNY.

Arvianto, I. R., \& Masduki, B. M. (2011, Juli 24). Penggunaan Multimedia Pembelajaran untuk Meningkatkan Pemahaman Konsep Siswa dengan Pendekatan Instruksional Concrete-Represetational-Abstract (CRA) (PTK Pada Siswa Kelas XI SMKN 1 Banyudono). Prosiding Seminar Nasional Matematika, 170-179.

Badan Pengembangan Sumber Daya Manusia Pendidikan dan Penjaminan Mutu Pendidikan. (2011). Pengembangan Instrumen Penilaian Pembelajaran Matematika SD/SM. (E. Prajitno, Ed.) Jakarta: Kementerian Pendidikan Nasional.

Depdiknas RI. (2003). Undang-undang No 20 Tahun 2003 tentang Sistem Pendidikan Nasional. Jakarta: Depdiknas.

Martono, N. (2014). Metode Penelitian Kuantitatif: Analisis Isi dan Analisis Data Sekunder (Revisi 2 ed.). (S. P. Utami, Ed.) Jakarta: Rajawali Pers.

Pebriani, R., Mulyati, T., \& Yuliariatiningsih, M. S. (2016). Penerapan Pendekatan Concrete-Representational-Abstract (CRA) Berbasis Masalah terhadap Kemampuan Pemecahan Masalah Matematis Siswa. Jurnal Antologi.

Putri, H. E. (2015). Pengaruh Pendekatan Concrete-Pictorial-Abstract (CPA) terhadap Peningkatan Kemampuan Representasi Matematis, Spatial Sense, dan Self-Efficacy Mahasiswa Calon Guru Sekolah Dasar [DISERTASI]. Bandung: Tidak diterbitkan.

Putri, H. E. (2015, June). The Influence of Concrete-Pictorial-Abstract (CPA) Approach to The Mathematical Repretentation Ability Achievement of The Pre-Teachers at Elementary School. International Journal of Education and Research, 3. Retrieved from www.ijern.com

Putri, H. E. (2017). Pendekatan Concrete-Pictorial-Abstract (CPA) Kemampuankemampuan Matematis \& Rancangan Pembelajarannya. (N. E. Suryani, \& R. Julianti, Eds.) Subang: Royyan Press. 
Putri, H. E., Rahayu, P., Saptini, R. D., \& Misnarti. (2016, Juli). Keterkaitan Penerapan Pendekatan CPA dan Peningkatan Kemampuan Koneksi Matematis Siswa SD. Metodik Didaktik, 43.

Siregar, H. (2013, Juni). Penberapan Model Pembelajaran Kooperatif Tipe STAD untuk Meningkatkan Aktivitas dan Hasil Belajar Siswa Kelas X-1 SMA Negeri 1 Tanjungpura pada Pelajaran Kimia. Jurnal Penelitian Tindakan Kelas, 2(1), 40-52.

Sugiyono. (2016). Metode Penelitian Kuantitatif, Kualitatif, dan R\&D. Bandung: Alfabeta.

Supardi, U. S. (2012). Pengaruh Pembelajaran Matematika Realistik terhadap Hasil Belajar Matematika ditinjau dari Motivasi Belajar. Cakrawala Pendidikan, 244-255.

Syam, N., \& Ramlah. (2015). Penerapan Model Pembelajaran Mind Mapping dalam Meningkatkan Hasil Belajar pada Mata Pelajaran Ilmu Pengetahuan Sosial Siswa Kelas IV SDN 54 Kota Parepare. Publikasi Pendidikan, V, 184-197. 